\title{
Literacy Education and Social Capital: A Study of Women's Involvement in Community Development Projects in Southwestern Nigeria
}

\author{
Adejoke Clara Babalola* (D) and Thomas Olusola Fasokun \\ Department of Adult Education and Lifelong Learning, Faculty of Education, \\ Obafemi Awolowo University, Ile-Ife, Nigeria
}

\begin{abstract}
The study examines the relationship between social capital and women's involvement in a community development project; assesses the relationship between rural women literacy level and social capital leverage, and determines the interaction effect of literacy level and social capital leverage on rural women involved in community development projects. This research was conducted in Southwestern Nigeria using a descriptive survey research design followed by qualitative methods for in-depth analysis. A multi-stage sampling procedure was used to select 720 rural women from randomly selected three states in Southwestern Nigeria. Moreover, we also conducted in-depth interviews with 12 women (6 each of literate and non-literate) who had indicated participation in community development projects and conducted a focus group discussion in each of the three selected states. The findings reveal that the most significant predictors of rural women involvement in community development are: participation in adult literacy programme; literacy level; strong interaction with people; membership of community development committees; participation in the decision making process and discussion of development issues with friends. Moreover, the number of literate women who made use of social capital to participate in community development is high. The study, therefore, concludes that the relationship between literacy and social capital is strong.
\end{abstract}

Keywords: Community; Development; Literacy education; Social capital; Women

* Corresponding Author.

jokebablo@gmail.com https://orcid.org/0000-0002-4800-6730
ISSN: 2091-0118(Print) /2091-2560(Online)

(C) 2019 The Author(s). Journal homepages: ${ }^{1}$ http://www.kusoed.edu.np/journal/index.php/je ${ }^{2}$ https://www.nepjol.info/index.php/JER/index 


\section{Introduction}

Literacy, according to UNESCO (2004), is the ability to read and write with understanding a simple statement related to one's daily life. Furthermore, UNESCO (2013), viewed literacy as an advancing set of skills, knowledge, and strategies that individuals build on throughout their lives in various contexts and through interaction with their peers and with the larger communities in which they participate. Literacy involves a continuum of learning in enabling individuals to achieve their goals, to develop their knowledge and potential, and to participate fully in their community and wider society (UNESCO, 2004).

There are a number of studies that looked at the influence of literacy education on women. For example, Oxenham (2009) stated that higher proportions of women who enrolled in literacy classes tended to have put their children in school, than illiterate mothers not enrolled in literacy classes. Furthermore, it has been discovered that participation in literacy education programmes helps women to develop stronger selfconfidence, to inspire greater respect among their family and community members, and to take more active roles in running and improving their communities. Significant effects of participation in literacy education also include the fact that it changed the ways of thinking, feeling and envisioning of the women. Women have been known to become self-confident and assertive. Thus, literacy was able to contribute not only to voting but also to state formation. It has also been reported that literacy participants can gain more voice in household discussions through having experience of speaking in the 'public' space of the class (Bhola \& Gómez, 2008; Fasokun \& Obilade, 1990).

Apart from the benefits mentioned above, literacy education should provide opportunities for its participants that will lead to building and drawing on social capital for community development. Putnam (2000) saw social capital as a key indicator of a community's capacity and readiness to successfully handle change by drawing on its "stocks of social capital" that can determine the likely success or failure of environmental and sustainability initiatives (as cited in Buys, Godber, Summerville, \& Barnett, 2007). 


\section{Literacy, Social Capital and Community Development}

Discussing literacy, community and social capital, Falk (2001) concluded that knowledge (of skills, literate resources, people, community and place) and identity resources (such as cultural norms and expectations, self-efficacy, roles in clubs, associations and families) come together in an indistinguishable fusion as the literate acts. It is the nature and frequency of interactions that impact on social capital by influencing the kinds of knowledge and identity resources made available or generated for achieving the actors' common purpose. For Kilpatrick and Falk (2001), social capital and learning have the potential to improve outcomes for communities by developing their capacity to manage change. Social capital resources that increase the capacity of a community are simultaneously built and drawn upon in learning interactions between individuals (Kilpatrick \& Falk 2001). In the same vein, Falk (2001) argues that the resources required for a community to build social capital are associated with knowledge and identity.

Moreover, Balatti and Falk (2001) in their study revealed strong evidence that adult learning can build social capital in the wider community. The study confirmed that the programme generated social capital through the creation of new social relations in the community that produced positive outcomes. As community-owned and community-based providers, the success of the programmes is very dependent on sharing resources and on shared ownership of the programmes by the communities they serve (Balatti \& Falk, 2001). Some of the research that had been carried out by Centre for Research and Learning in Regional Australia revealed that effective programmes provide an environment containing opportunities for the social capital building to occur for their learners (Balatti \& Falk, 2001; Falk \& Kilpatrick, 2000).

Balatti and Falk (2001) believe literacy education should create opportunities for learners to interact with groups, situations and contexts outside those of their immediate communities. The interactions also increase people's confidence to act for the benefit of the community and its members, develop shared values and build a commitment to members of the community and the community as a whole. Thus, social capital is dynamic and is simultaneously used and built through learning processes (Kilpatrick \& Falk, 2001). 


\section{4 |A. C. Babalola \& T. O. Fasokun}

\section{Testing Social Capital}

Social capital is the connections among individuals - social networks and the norms of reciprocity and trustworthiness that arise from them; the aggregate of the actual or potential resources which are linked to possession of a durable network of more or less institutionalized relationships of mutual acquaintance and recognition. By its function, it is not a single entity, but a variety of different entities which consist of some aspects of a social structure, that facilitate certain actions of individuals who are within the structure (Bourdieu, 1983; Coleman, 1994; Putnam 2000; as cited in Smith, 2009). Social capital is created when individuals and groups exchange, share and give their human capital and other resources they command through social transactions within the context of relationships. Social capital is not social support; rather, it is a means for gaining access to social support (Bernosky de Flores, 2010). Stone (2003) highlighting three forms of social capital: bonding, bridging and linking described social capital as a concept that describes the extent and nature of relationships people have with others, the relationships people have with their communities, and relationships between people and various services, institutions and systems. It is also a concept that can be used to understand the linkages between communities or institutions. Bonding social capital involves trust and reciprocity in closed networks (in which members of networks know other members), and helps the process of 'getting by' in life on a daily basis. 'Getting ahead' in contrast, is facilitated through 'cross-cutting ties' that take the form of either bridging or linking social capital. Bridging social capital involves overlapping networks (in which a member of one group can gain access to the resources of another group because of overlapping membership). Linking social capital involves social relations with those in authority, which might be used to garner resources or power (Stone 2003).

Bonding social capital, which is the close-knit tie among similar individuals or groups, is said to be good for "getting by," whereas the bridging form, representing "weaker" ties among heterogeneous individuals or groups, connects one to new resources, and is needed to "get ahead" (Agnitsch, Kerry, Flora, \& Ryan, 2006). The 'bonding' and 'bridging' ties identified in the social capital literature by Falk and Kilpatrick (2000) enable the sharing of skills, knowledge and resources within the group for example in a community, while at the same time accessing outside resources. There is the belief that social capacity is greater where people are willing and able to 
work together for mutual benefit, which means they have sufficient confidence, appropriate norms and interpersonal skills such as conflict resolution.

Furthermore, Grootaert, Narayan, Jones, and Woolcock (2003) concluded that social trust is one dimension of "bonding social capital," which ties together people living in the same community and sharing some demographic characteristics. Also, according to Luhman (1995), "the everyday social life which we have taken for granted is simply not possible without trust" (as cited in Moazami, 2006, p. 85). Trust is the most widely used indicator in the measurement of social capital. Trust means to have belief or confidence in the honesty, goodness, skill, or security of a person or an organisation. Likewise, Misztal (2001) attempts to combine all notions of trust together by suggesting that there are three basic things that trust does in the lives of people: It makes social life predictable; it creates a sense of community, and it makes it easier for people to work together (as cited in Moazami, 2006). The results of the research carried out by Moazami (2006) also showed that trust among farmers has a positive and significant effect on farmers' willingness to participate in collective activities, though its effect is not very considerable. Grootaert's (2002) hypothesised that if an individual trusts other individuals, he is more willing to participate in collective activities in the community (as cited in Moazami, 2006).

\section{Measuring Levels of Literacy}

There are varieties of tools and terms to measure and describe literacy levels because measuring literacy is complex and subject to significant data limitations. Washington State Institute for Public Policy (WSIPP) (2008) defining literacy in terms of forms and measurements, gave two definitions of literacy as 'Absolute' which determines an individual's literacy status by grade level and 'Relative' which uses an individual's ability to complete reading and writing tasks in a specific cultural or social context.

While some authors make use of years of schooling to measure literacy, National Adult Literacy Survey (NALS) 1992 measured document, prose, and quantitative, where five levels of literacy are identified (1 through 5). Also, National Adult Assessment of Literacy (NAAL) in 2003 measured document, prose, and quantitative literacy, using a point scale of 1-500 and also identified four descriptive levels of literacy (WSIPP, 2008). 
Literacy Assessment and Monitoring Programme (LAMP) measures five levels of literacy, which were summarized by UNESCO (2009) as:

- Level 1 indicates persons with very poor skills.

- Level 2 refers to respondents who can deal only with material that is simple, clearly laid out, and in which the tasks involved are not too complex.

- Level 3 roughly denotes the skill level formally required for successful secondary school completion and entry to tertiary-level educational institutions.

- Levels 4 and 5 describe respondents who demonstrate a command of higher-order information processing skills.

For this study, the level of literacy was measured using the LAMP's five measures of levels of literacy, which were summarized by UNESCO (2009). This study is therefore interested in exploring the relationship between women's literacy level, social capital and the effects on women's participation in issues concerning community development process. It also involves how women's participation in adult literacy education programme and relationship that women form then become assets to community development. This focus has not attracted the attention of adult educators in Nigeria. Also, of significance is the issue of trust starting from families, people cannot leave together unless they trust one another. In our everyday social life, we often work easily with people that we trust. In community development, the importance of social trust which has been discussed above as a dimension of bonding social capital cannot be over-emphasised. There have been many studies on social capital and also on literacy from other countries, but it will be necessary to find out the effects that literacy and social capital can have on rural women's involvement in community development in the rural areas of South-western part of Nigeria, hence this study.

\section{Conceptual Framework}

The indicators of literacy used are levels of literacy (levels 1-5), literacy status (ability to read and write) and participation in adult literacy programmes. The study also examined the effects of literacy on one dimension of social capital: bonding and its effect on the involvement of women in community development projects. The indicators of social capital that were tested in this study were strong interaction with people; discussion of development issues with friends and individually calling for project support. Also, it was tested if membership of community development 
association / community-based association and participation in decision making will lead to participation in community development in the study area. Also tested were participation in an adult literacy programme, meeting new friends at the centre, women's meeting to discuss development project with friends and relatives within the neighbourhood.

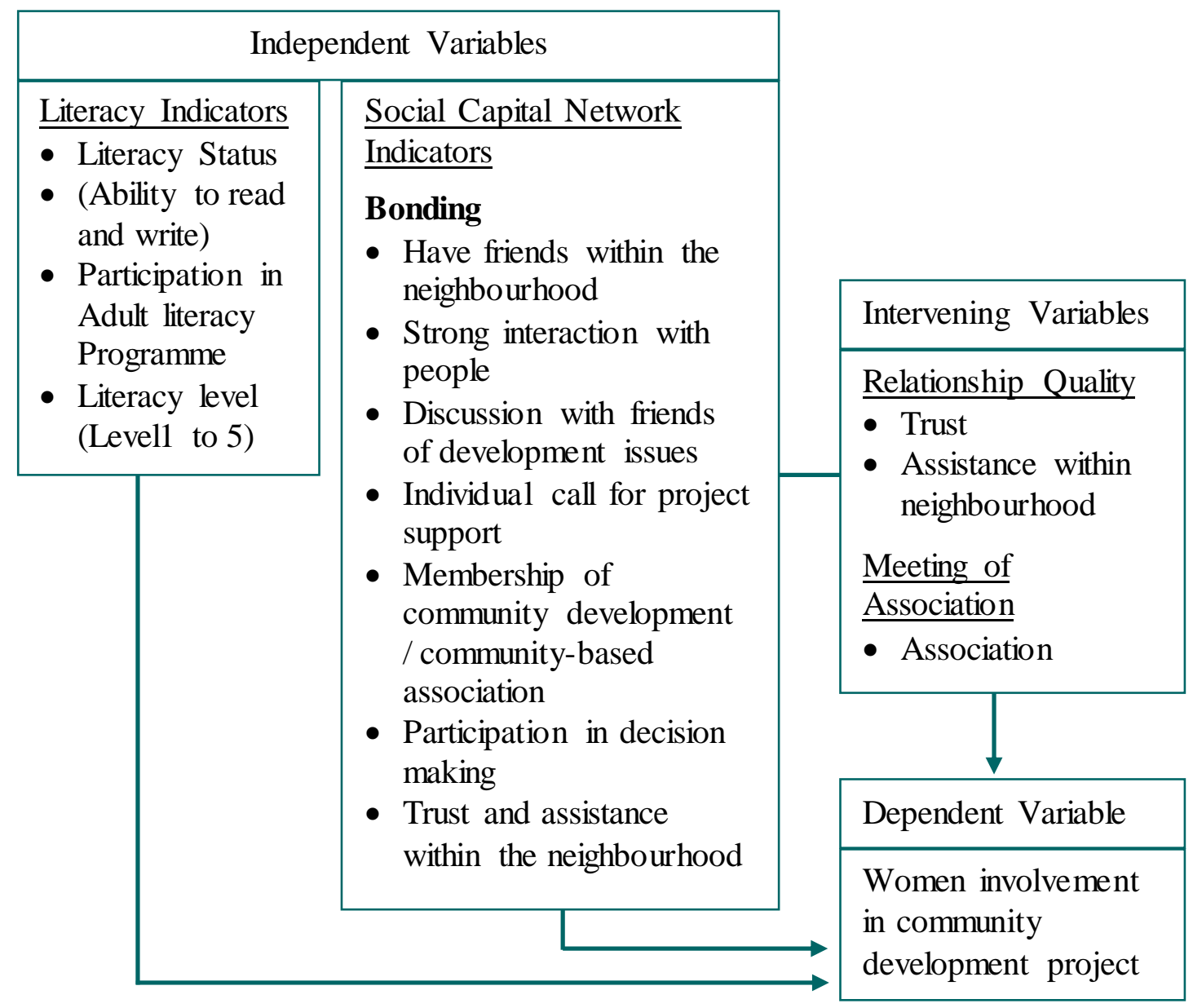

Figure 1. Conceptual Framework showing the interrelationships between literacy, social capital and rural women involvement in community development projects 
98 |A. C. Babalola \& T. O. Fasokun

The specific objectives of the study are to:

i. examine the relationship between social capital and women's involvement in a community development project;

ii. assess the relationship between rural women literacy level and social capital leverage; and

iii. determine the interaction effect of literacy level and social capital leverage on rural women involvement in community development projects.

\section{Research Hypothesis}

There is no significant relationship between literacy and the way women use social capital for community development.

\section{Methodology}

Data on rural women's literacy level, social capital and involvement in community development projects were used for this study. The research design that was adopted for this study is the descriptive survey. This research was conducted in Southwestern Nigeria (one of the six geo-political zones of Nigeria). The study was restricted to this geo-political zone (Southwest) to have an in-depth knowledge of the relationship between rural women's literacy level, social capital and their involvement in community development projects. The population for the study consists of all women in the rural areas of Southwestern Nigeria.

The random sampling technique was used to select three states out of six states in Southwestern Nigeria. From each of the selected states, two local government areas (LGA) were selected using random sampling technique, and from each of the selected LGAs, two rural communities were randomly selected as primary sampling unit for this study and from each rural community, 60 women were selected making a total number of 720 .

This study made use of both quantitative and qualitative methods to prevent the limitation that can arise from using one type of data. Therefore, the qualitative data were used to obtain in-depth knowledge about the study to strengthen that quantitative data. Three types of the instrument were used to collect data for this study. The qualitative method was used to have a wide coverage about the study. The quantitative

Journal of Education and Research, Vol. 9, No. 1, 2019 
data used for this study was obtained through a self-structured interviewer`s administered questionnaire on a regional representative sample of eligible respondents within all regular households in the rural South-western parts of Nigeria. The questionnaire was administered by the interviewer on one on one basis because the target population comprised of women residing in the South-western rural areas and it was expected that many of them might not be able to read or write.

In addition to the quantitative data, data were also obtained through in-depth interviews (IDI) and the Focus Group Discussion (FGD). For the in-depth interview, the study used purposive sampling technique to select 2 women (literate and nonliterate) from each of the local government areas selected, making a total of 12 women who had indicated participation in community development projects. For these women, in-depth interviews were conducted to get information on their personal feelings, opinions, experience on literacy education, social capital and their involvement in community development projects. The study also conducted an FGD in each of the selected states to elicit information on groups' opinions about community development and the rate at which women were able to use literacy and social capital for community development projects. In all, twelve (12) in-depth interviews and 3 FGDs were conducted and these were considered adequate because of the qualitative nature of data sought and limited resources available for the study. The research instruments used were an in-depth interview guide and an FGD guide. Both instruments permitted a greater depth of meaning and detailed and open-ended responses to questions. The two guides contained outlines of topics and a set of general questions, and details that were not brought out initially were sought through follow-up questions or probes. The qualitative data collected were used to corroborate the findings from the qualitative data. 
$100 \mid$ A. C. Babalola \& T. O. Fasokun

\section{Findings and Discussion}

Researchobjective 1: To examine the relationship between social capital and women's involvement in a community development project

Table 1

Percentage Distribution of Rural Women's Social Capital Leverage (Bonding) and Their Involvement in the Community Development Project

\begin{tabular}{|c|c|c|c|c|c|}
\hline Variables & \multicolumn{2}{|c|}{$\begin{array}{l}\text { Involvement in Community } \\
\text { Development Project }\end{array}$} & Total & $\begin{array}{l}\mathrm{Chi}^{2} \text { - } \\
\text { value }\end{array}$ & $\begin{array}{l}\text { P- } \\
\text { value }\end{array}$ \\
\hline \multicolumn{6}{|c|}{ Participated at the decision-making level } \\
\hline Yes & $189(89.57)$ & $22(10.43)$ & 211 & & \\
\hline No & $299(58.74)$ & $210(41.26)$ & 509 & 64.9225 & 0.0001 \\
\hline Total & $488(67.78)$ & $232(32.22)$ & 720 & & \\
\hline \multicolumn{6}{|c|}{ Involved in the discussion of community dev. issues with other women } \\
\hline Yes & $380(75.25)$ & $125(24.75)$ & 505 & & \\
\hline No & $101(49.51)$ & $103(50.49)$ & 204 & 44.1192 & 0.0005 \\
\hline Total & $481(67.84)$ & $228(32.16)$ & 709 & & \\
\hline \multicolumn{6}{|c|}{ My relationship with a friend has brought about development. } \\
\hline Yes & $133(78.24)$ & $37(21.76)$ & 170 & & \\
\hline No & $57(48.31)$ & $61(51.69)$ & 118 & 27.7948 & 0.0007 \\
\hline Total & $190(65.97)$ & $98(34.03)$ & 288 & & \\
\hline \multicolumn{6}{|c|}{ Have friends \& relatives within or outside this neighbourhood } \\
\hline Yes & $446(69.10)$ & $200(30.9)$ & 644 & & \\
\hline No & $42(56.16)$ & $32(43.84)$ & 73 & 5.0236 & 0.0232 \\
\hline Total & $488(67.78)$ & $232(32.22)$ & 720 & & \\
\hline
\end{tabular}

Notes: $* \mathrm{p}<0.05$ Source: Field Work (Babalola, 2014)

Table 1 showed a significant relationship between women's participation at the decision-making level and involvement in development processes $(2=64.9225, \mathrm{p}<$ 0.05). It further revealed that the percentage of women's involvement in community development project was $30 \%$ point greater among those who participated at the 
decision-making level than those who did not participate at the decision-making level $(89.57 \%$ versus $58.74 \%)$.

Besides, $(75.25 \%)$ of the women who discussed community development issues with other women were involved in community development project than those who did not discuss development issues $(49.51 \%)$ with other women within or outside the village. Meanwhile, $78.24 \%$ versus $21.76 \%$ of the women who said that their relationship with friends within and outside the village had brought about community development in one way or the other was involved in community development projects more than their counterparts $(48.31 \%$ versus $51.69 \%)$ who were not involved in community development.

Likewise, the study found a significant relationship between women's involvement in the community development project and having friends within or outside their neighbourhood $(2=5.0236, \mathrm{p}<0.05)$. Women who had close friends within and outside $(69.10 \%)$ their neighbourhood were much more involved in community development project than those who did not have close friends $(56.78 \%)$. This finding is in line with Agnitsch et al. (2006) who stated that the main premise behind social capital was that well-connected individuals or groups are better able to mobilize other resources to pursue desired outcomes. In terms of community action, a well-connected community (i.e. one with "community social capital") should be better able to mobilize local and extra-local resources to effectively act, and indeed, this idea has been empirically supported.

Table 2

Percentage Distribution of Rural Women's Leverage of Social Capital - Trust (Dimension of Bonding Social Capital) and Their Involvement in Community Development Project

\begin{tabular}{|c|c|c|c|c|c|}
\hline $\begin{array}{l}\text { Variables } \\
\text { (Socio-capital } \\
\text { trust) }\end{array}$ & \multicolumn{2}{|c|}{$\begin{array}{l}\text { Involvement in Community } \\
\text { Development Project }\end{array}$} & Total & $\begin{array}{l}\mathrm{Chi}^{2}- \\
\text { value }\end{array}$ & $\begin{array}{l}P \text { - } \\
\text { value }\end{array}$ \\
\hline \multicolumn{6}{|c|}{ If I have a problem, there is always someone to help. } \\
\hline Agree & 385 (71.96) & $150(28.04)$ & 535 & & \\
\hline Undecided & $22(66.67)$ & $11(33.33)$ & 33 & 18.9183 & 0.0029 \\
\hline Disagree & $81(53.29)$ & $71(46.71)$ & 152 & & \\
\hline
\end{tabular}


102 |A. C. Babalola \& T. O. Fasokun

Total $488(67.78) \quad 232(32.22) \quad 720$

Most people in this neighbourhood are willing to help.

$\begin{array}{llllll}\text { Agree } & 372(71.40) & 149(28.60) & 521 & & \\ \text { Undecided } & 68(67.33) & 33(32.67) & 101 & 18.9982 & 0.0015 \\ \text { Disagree } & 48(48.98) & 50(51.02) & 98 & & \\ \text { Total } & 488(67.78) & 232(32.22) & 720 & & \end{array}$

My relationship with friends within \& outside the community has brought dev.

$\begin{array}{llllll}\text { Agree } & 243(79.41) & 63(20.59) & 306 & & \\ \text { Undecided } & 106(63.86) & 60(36.14) & 166 & 35.7565 & 0.003 \\ \text { Disagree } & 139(56.05) & 109(43.95) & 248 & & \\ \text { Total } & 488(67.78) & 232(32.22) & 720 & & \end{array}$

By working together, we do influence the decision concerning our village.

\begin{tabular}{llllll} 
Agree & $351(72.07)$ & $136(27.93)$ & 487 & & \\
Undecided & $65(63.11)$ & $38(36.89)$ & 103 & 14.2872 & 0.0288 \\
Disagree & $72(55.38)$ & $58(44.62)$ & 130 & & \\
Total & $488(67.78)$ & $232(32.22)$ & 720 & & \\
\hline
\end{tabular}

Notes: $* \mathrm{p}<0.05$

Source: Field Work (Babalola, 2014)

Social capital also refers to generalized norms, attitudes, and values among individuals. It also includes trust and solidarity, which together determine the level of interactions and relationships between individuals and associations. The existence of this interaction and relationship between individuals, groups, associations and communities can actually solidify into trust and solidarity and also build confidence in people to assist each other and also harness resources together for community development (Moazami, 2006). Our findings on the relationship between social capitaltrust (at all levels of measurement) and rural women's involvement in community development projects revealed a significant relationship. The result showed that majority $(71.96 \%$ versus $28.04 \%$ ) of the women who were confident of having someone to help if the need arose were more involved in community development project compared with women who were not confident of having someone to help if the need arose $(66.67 \%$ versus $33.33 \%)$ and those who could not decide whether they had people they could turn to or not (53.29\% and $46.71 \%)$.

Journal of Education and Research, Vol. 9, No. 1, 2019 
Also, there exists a significant association between willingness to help among women within the same neighbourhood and their involvement in a community development project $(2=18.9982, \mathrm{p}<0.05)$. The percentage of involvement in community development among women who lived within a neighbourhood where people were willing to help $(71.40 \%$ versus $30.97 \%)$ was $10 \%$ point greater than the percentage of involvement among those who lived within the neighbourhood where people were not willing to help (61.54\% versus $38.46 \%)$ and those who could not decide $(60.42 \%$ versus $39.58 \%)$ whether they lived within the neighbourhood where people were willing to help or not.

Also, a majority (79.41 versus $20.59 \%$ ) of women who reported that their relationship with friends had brought about community development were much more involved in the development process than their counterpart who disagreed $(56.05 \%$ versus $43.95 \%$ ) and those who could not decide (63.86\% versus $36.14 \%$ ). Also, majority of the women who reported that they had influenced decisions concerning their village by working together with other women within the village $(72.07 \%$ versus $27.93 \%$ ), were much more involved in community development project than their counterparts $(55.38 \%$ versus $44.62 \%$ ) who disagreed by saying that their working together with other women had not influenced any decision concerning development projects in their villages. Whereas, $63.11 \%$ versus $36.89 \%$ of others who were involved in a community development project could not decide whether their working together had influenced any decisions concerning their village development. Bonded solidarity creates social capital when individuals and groups share or pool their human capital and or resources to achieve a common goal (Graddy \& Wang, 2009). This result suggests that social capital is a useful tool in community development. 
104 |A. C. Babalola \& T. O. Fasokun

Researchobjective 2: To assess the relationship between rural women's literacy level and social capital leverage

Table 3

Percentage Distribution of the Relationship between Rural Women Literacy Level and Membership of Association

\begin{tabular}{|c|c|c|c|c|c|}
\hline \multirow{2}{*}{$\begin{array}{l}\text { Level of } \\
\text { Education }\end{array}$} & \multicolumn{2}{|c|}{ Membership of Association } & \multirow[t]{2}{*}{ Total } & \multirow{2}{*}{$\begin{array}{l}\mathrm{Chi}^{2}- \\
\text { value }\end{array}$} & \multirow[t]{2}{*}{ P-value } \\
\hline & Yes $(\%)$ & No $(\%)$ & & & \\
\hline No education & $166(79.05)$ & $44(20.95)$ & 210 & & \\
\hline Level 2 & $200(85.11)$ & $35(14.89)$ & 235 & 3.0537 & 0.2239 \\
\hline Level 3 & $206(80.47)$ & $50(19.53)$ & 256 & & \\
\hline Levels 4 \&5 & $13(81.25)$ & $3(18.75)$ & 16 & & \\
\hline Total & $585(81.59)$ & $132(18.41)$ & 717 & & \\
\hline
\end{tabular}

Note: P < 0.05Source: Field Work (Babalola, 2014)

Membership of one association or the other was tested here as bonding. Women in the rural areas belonged to associations whether they were literate or not. This could be because these associations were needed to transact one business or the other in other to earn a living. Findings from this analysis in Table 3 showed that there was no significant relationship $(2=3.0537, \mathrm{p}>0.05)$ between rural women literacy level and their membership of the association. However, the analysis revealed that the proportion of women in one association or the other increased with the level of education: from $79.05 \%$ to $85.11 \%$ for no education and level 2; and from $80.47 \%$ to $81.25 \%$ for level 3 and level $4 \& 5$ respectively.

Table 4

Percentage Distribution of Respondents by Availability of Community Developmental Committee/Association (CDC/CDA) and Proportion of Women in that Committee and the proportion who are literate

\begin{tabular}{lcr}
\hline Variables & Frequency & \multicolumn{2}{c}{ Percentage } \\
\hline Are there developmental committee/association in this community? & \\
Yes & 623 & 86.53 \\
No & 97 & 13.47 \\
Total & 720 & 100
\end{tabular}

Journal of Education and Research, Vol. 9, No. 1, 2019 
What proportion of your committee are women?

one-fourth

one-third

than one-third

Total

Proportions of the committee that are literate

One-third

Less than one-third

Almost half

Others

Source: Field Work (Babalola, 2014)

Majority of the villages had CDC/CDA as reported by (86.53\%) of the women. Information on the proportion of the committees that had women showed that women were not properly represented in the committees as their proportion in all the committees was not up to half of the committees, ranges from: one fourth $(51.34 \%)$; less than one third $(19.92 \%)$; to one third $(28.74 \%)$. Meanwhile, of those women in the committee, the proportion of those that were literate ranged from: less than one third (38.83\%); one third (39.42\%); to almost half (19.61\%) in all the villages. Findings from the FGD and the In-depth interview show that in the villages where we have CDC, some of the CDC do not have women as members and of those that have women as members, the proportion of women among them is very minute. This is in line with the findings in the table above which shows that women were not well represented. For example, a non-literate woman from Arege Village, Odeda LGA) stated:

.... We have community development committee and there are up to three women among them. These women do contribute to any decision that will be made.

Another literate woman in Aseigbo Village, Owena LGA who also confirmed:

.... I am a member of CDA, and we also have subcommittee comprised of women only that monitor the electrification of our village.

The rest of the women interviewed also corroborated what the others mentioned. 
$106 \mid$ A. C. Babalola \& T. O. Fasokun

... We have $C D C$, but we have only one woman among them.(a non-literate woman in Ereje Village, Ondo East LGA)

...... We have a community development committee (CDC), but we don't have women among them. Once the committee decides on what to do, they will gather us to inform us. (a literate woman in Idiaraba Village, Oriade LGA]

... We have $C D C$, but we have only one woman among them ... [a non-literate woman in Ereje Village, Ondo East LGA]

Research objective 3: To determine the interaction effect of literacy level and social capital leverage on rural women involvement in community development projects.

Table 5

Analysis of Variance of the Interaction Effect of Literacy Status and Leverage of Social capital on Involvement in Community Development

\begin{tabular}{lccccc}
\hline Source & Partial SS & Df & Ms & F & Prob > F \\
\hline Model & 41913.9346 & 3 & 13971.3115 & 12.48 & 12.48 \\
Literacy & 7124.29051 & 1 & 7124.29051 & 6.36 & 0.0119 \\
Social capital & 22072.8981 & 1 & 22072.8981 & 19.72 & 0.0000 \\
$\begin{array}{l}\text { literacy\#Social } \\
\text { capital }\end{array}$ & 1581.62756 & 1 & 1581.62756 & 1.41 & 0.2350 \\
$\begin{array}{l}\text { Residual } \\
\text { Total }\end{array}$ & 794711.887 & 710 & 1119.31252 & & \\
& 836625.822 & 713 & 1173.38825 & &
\end{tabular}

Number of obs $=714 \quad$ R-squared $=0.0501$

Root MSE $=33.4561 \quad$ Adj R-squared $=0.0461$

Findings from this analysis revealed a significant difference in the rural women literacy status, their social capital as it related to their involvement in community development $(\mathrm{p}<0.05)$. That is, rural women who were literate and also leveraging their social capital were more involved in the community development project than their counterparts. Furthermore, the analysis further showed that there was a significant

Journal of Education and Research, Vol. 9, No. 1, 2019 
Literacy Education and Social Capital| 107

mean interaction effect between literacy status and social capital leverage as it related to rural women's involvement in community development $(p<0.05)$.

Table 6

Analysis of Variance of the Interaction Effect of Literacy Level and Leverage of Social Capital on Involvement in Community Development

\begin{tabular}{lrlrrr}
\hline \multicolumn{1}{c}{ Source } & Partial SS & Df & Ms & F & Prob > F \\
\hline Model & 46351.4868 & 7 & 6621.64098 & 5.92 & 0.0000 \\
Literacy level & 9777.99352 & 3 & 3259.33117 & 2.91 & 0.0337 \\
Social capital & 3214.89005 & 1 & 3214.89005 & 2.87 & 0.019 \\
$\begin{array}{l}\text { Literacy level\#Social } \\
\text { capital }\end{array}$ & 4548.69701 & 3 & 1516.23234 & 1.35 & 0.0254 \\
Residual & 790274.335 & 706 & 1119.36875 & & \\
Total & 836625.822 & 713 & 1173.38825 & & \\
\hline
\end{tabular}

Number of obs $=714 \quad$ R-squared $=0.0554$

Root MSE $=33.457 \quad$ Adj R-squared $=0.0460$

Source: Field Work (Babalola, 2014)

Findings from this analysis revealed a significant combination effect $(\mathrm{F}=1.35, \mathrm{P}=$ 0.03 ) of rural women's literacy level and their social capital on their involvement in community development. That is, rural women who were literate at any level or who were leveraging their social capital were more involved in community development project than their counterparts who were non-literate or not leveraging their social capital. Furthermore, the analysis showed that there was a significant mean interaction effect between literacy level and social capital leverage on rural women involvement in community development $(\mathrm{p}<0.05)$. 
108 |A. C. Babalola \& T. O. Fasokun

Table 7

Percentage Distribution of Respondents' Views on Social Capital Leverage (Relationship Quality, Participation in Literacy Education) and Involvement in Community Development Project

\begin{tabular}{|c|c|c|c|c|}
\hline \multirow{2}{*}{ Variables of interest } & \multirow{2}{*}{$\begin{array}{l}\text { Freq. (\%) } \\
\text { Agree }\end{array}$} & \multirow{2}{*}{$\begin{array}{l}\text { Freq. (\%) } \\
\text { Undecided }\end{array}$} & \multicolumn{2}{|l|}{ Freq. (\%) } \\
\hline & & & Disagree & Total \\
\hline $\begin{array}{l}\text { If I have any problem, I have } \\
\text { people to run to in this village. }\end{array}$ & $\begin{array}{l}535 \\
(74.31)\end{array}$ & $33(4.58)$ & $152(21.1)$ & 720 \\
\hline $\begin{array}{l}\text { People in this neighbourhood are } \\
\text { willing to help. }\end{array}$ & $\begin{array}{l}521 \\
(72.36)\end{array}$ & $\begin{array}{l}101 \\
(14.03)\end{array}$ & $98(13.61)$ & 720 \\
\hline $\begin{array}{l}\text { This village has prospered in the } \\
\text { last five years. }\end{array}$ & $\begin{array}{l}425 \\
(59.03)\end{array}$ & $\begin{array}{l}133 \\
(18.47)\end{array}$ & $\begin{array}{l}162 \\
(22.50)\end{array}$ & 720 \\
\hline $\begin{array}{l}\text { Educated women are always } \\
\text { involved in comm. development }\end{array}$ & $\begin{array}{l}366 \\
(51.05)\end{array}$ & $\begin{array}{l}182 \\
(25.38)\end{array}$ & $\begin{array}{l}169 \\
(23.57)\end{array}$ & 717 \\
\hline $\begin{array}{l}\text { My participation in a literacy } \\
\text { programme influences my } \\
\text { relationship with others in this } \\
\text { village. }\end{array}$ & $\begin{array}{l}178 \\
(28.66)\end{array}$ & $\begin{array}{l}228 \\
(36.71)\end{array}$ & $\begin{array}{l}215 \\
(34.62)\end{array}$ & 621 \\
\hline $\begin{array}{l}\text { My relationship with friends } \\
\text { within \&outside has brought } \\
\text { development }\end{array}$ & $\begin{array}{l}306 \\
(42.50)\end{array}$ & $\begin{array}{l}166 \\
(23.06)\end{array}$ & $\begin{array}{l}248 \\
(34.44)\end{array}$ & 720 \\
\hline $\begin{array}{l}\text { We meet with people in authority } \\
\text { to get things done. }\end{array}$ & $\begin{array}{l}321 \\
(44.71)\end{array}$ & $\begin{array}{l}187 \\
(26.04)\end{array}$ & $\begin{array}{l}210 \\
(29.25)\end{array}$ & 718 \\
\hline $\begin{array}{l}\text { I can influence the decision } \\
\text { affecting my village. }\end{array}$ & $\begin{array}{l}241 \\
(33.47)\end{array}$ & $\begin{array}{l}168 \\
(23.33)\end{array}$ & $\begin{array}{l}311 \\
(43.19)\end{array}$ & 720 \\
\hline $\begin{array}{l}\text { By working together, people in } \\
\text { my village do influence decision } \\
\text { concerning our village. }\end{array}$ & $\begin{array}{l}487 \\
(67.64)\end{array}$ & $\begin{array}{l}103 \\
(14.31)\end{array}$ & $\begin{array}{l}130 \\
(18.06)\end{array}$ & 720 \\
\hline
\end{tabular}

Source: Field Work (Babalola, 2014)

Table 7 above revealed that $74.31 \%$ as against $21.1 \%$ of the women always had people to run to if they had a problem while $4.58 \%$ of them were undecided. More than Journal of Education and Research, Vol. 9, No. 1, 2019 
two thirds $(72.36 \%)$ of them agreed that people in their neighbourhood were always willing to help if called upon while less than one fifth (13.61\%) of them disagreed and $14.03 \%$ were undecided on this issue.

Also, (59.03\% versus $22.50 \%$ ) of the villagers (rural women) believed that their village had prospered in the last five years while $18.47 \%$ of them could not really say whether their village had prospered in the last five years or not. A bit more than average $(51.05 \%)$ of the women agreed that educated women were always involved in community development project while less than one third $(23.57 \%)$ of the women disagreed with this statement and $25.38 \%$ of them were undecided. Of those that participated in a literacy programme, less than one third $(28.66 \%)$ affirmed that their participation in the literacy programme had influenced their relationship with others in the village while more than one third disagreed $(34.62 \%)$ and $(36.71 \%)$ were undecided about the statement respectively.

In addition, $42.50 \%$ versus $34.44 \%$ of the women agreed and disagreed respectively that their relationship with friends within and outside the village had brought about community development while $23.06 \%$ of the rest were undecided. Meanwhile, $44.71 \%$ of them agreed that they always met with friends to get things done as against $29.25 \%$ and $26.04 \%$ of those that disagreed and were undecided with the statement respectively. In all, $67.64 \%$ of the women affirmed that by working together, people in their village did influence decision concerning the development of their village. The women who were interviewed also confirmed the fact that literate women were able to assist their neighbours to build social capital and also participate in some sort of community development. For instance, a literate woman in Ajibawo Village, Ado-Odo Ota LGA said:

I'm the secretary and treasurer of my association, in the church; also, I'm the treasurer... so, that is the way I have been helping my neighbours and my community with my little education.

Another with even lower level of education was of assistance to her neighbours, who said:

...Though I only attended primary six, it has helped me in assisting my neighbours; for instance, I do help them to write letters and to read text messages or letter... " [a literate woman in Arege Village, Odeda LGA] 


\section{$110 \mid$ A. C. Babalola \& T. O. Fasokun}

Others are very independent and can assist because of their literacy level. Below are the comments of the women:

.... As I am now, 'my colleagues cannot cheat me', if they speak, I will also speak, and I can enter anywhere and no one can challenge me... [a literate woman in Oboto Village, Ondo East LGA]

...My level of education really assisted me to have a good relationship with my neighbours...[a literate woman in Oboto Village, Ondo East LGA]

... With my little education, I have more knowledge and I have been helping my

neighbours with it... [a literate woman in Ajibawo Village, Owena LGA]

Therefore, it can be said that qualitative responses above show three important indicators of bonding namely: friendship within the neighbourhood, strong interaction with people and, trust and assistance within the neighbourhood. Bonding is one of the types of social capital identified by Stone (2003). The participants were able to use social capital to influence other people in their respective communities thereby fostering community development. The responses indicated that the ability of these women to use social capital positively was fostered largely by their levels of literacy. The women specifically attributed their ability to get along with others to their literacy abilities, one of the women became assertive speaking in the 'public' space (Bhola \& Gómez, 2008; Fasokun \& Obilade, 1990).

\section{Research Hypothesis}

"There is no significant relationship between literacy and the way women use social capital for community development. 
Table 8

Odds Ratio from the General Binary Logistic Regression Model Ifor the Likelihood of Rural Women Involvement in Development Process

\begin{tabular}{|c|c|c|c|}
\hline \multirow{2}{*}{$\begin{array}{l}\text { Variables } \\
\text { Literacy \& Bonding Indicators }\end{array}$} & \multicolumn{3}{|c|}{$\begin{array}{l}\text { Rural women involvement in } \\
\text { Developmental Project }\end{array}$} \\
\hline & $\begin{array}{l}\text { Odds-ratio } \\
\text { (std. error) }\end{array}$ & p-value & $\begin{array}{l}\text { [95\% Conf. } \\
\text { Int.] }\end{array}$ \\
\hline \multicolumn{4}{|l|}{ Literacy Status } \\
\hline Non-literate & $\mathrm{RC}$ & & \\
\hline Literate & $1.31(0.43)$ & 0.408 & $0.69-2.50$ \\
\hline \multicolumn{4}{|c|}{ Participation in Adult literacy programme } \\
\hline No & $\mathrm{RC}$ & & \\
\hline Yes & $2.47(0.77)$ & $0.004 *$ & $1.35-4.54$ \\
\hline \multicolumn{4}{|l|}{ Socio capital-Bonding } \\
\hline \multicolumn{4}{|l|}{ Strong interaction with people } \\
\hline Yes & $4.90(1.50)$ & $0.000^{*}$ & $2.69-8.93$ \\
\hline \multicolumn{3}{|l|}{ Have friends within \& outside } & \\
\hline No & $\mathrm{RC}$ & & \\
\hline Yes & $1.10(0.56)$ & 0.845 & $0.41-2.97$ \\
\hline \multicolumn{4}{|c|}{ Member of development committee } \\
\hline No & $\mathrm{RC}$ & & \\
\hline Yes & $1.50(0.49)$ & 0.215 & $0.79-2.85$ \\
\hline \multicolumn{4}{|l|}{ Participate in Decision making } \\
\hline No & $\mathrm{RC}$ & & \\
\hline Yes & $4.80(1.40)$ & $0.000^{*}$ & $2.70-8.52$ \\
\hline \multicolumn{4}{|c|}{ Discussion of dev. issues with friends } \\
\hline No & $\mathrm{RC}$ & & \\
\hline Yes & $2.29(0.60)$ & $0.002 *$ & $1.37-3.82$ \\
\hline
\end{tabular}

Notes: $* \mathrm{p}<0.05$

$\mathrm{RC}=$ reference category

Standard errors are in parenthesis - (std. - error)

Model I = model built with literacy factors \& social capital-bonding

Source: Field Work (Babalola, 2014)

Journal of Education and Research, Vol. 9, No. 1, 2019 
This section involved the combination of literacy factors (ability to read and write and participation in adult literacy programme) and social capital bonding indicators (having close friends within and outside their neighbourhood, membership of development committee, participation in decision making, acceptance of women's ideas on developmental issues and discussion of development issues with friends) as predictors of rural women's involvement in community development projects (explanatory variables). The dependent variable, however, is the involvement of rural women in any community development project at any level of participation and support.

This was actually designed to observe the variation in the likelihood of rural women's involvement in community development based on their literacy factors, leverage of their social capital and the inter-relationships among these factors. The result of the logistic regression, therefore, shows that the most significant predictors of rural women involvement in community development are: participation in the adult literacy programme, strong interaction with people, participation in the decisionmaking process and discussion of development issues with friends. Though not statistically significant, the odds of rural women's involvement in community development increased steadily with literacy status such that literate women are more likely to be involved in community development project than (OR 1.31; p > 0.05; C.I. $0.69-2.50)$ their non-literate counterparts.

The study also found a significant relationship between women's participation in the adult literacy programme and their involvement in community development. Women who participate in adult literacy programme are twice more likely to be involved in community development (OR 2.47; $\mathrm{p}<0.05$; C.I $.35-4.54$ ) project than their counterparts who do not participate in the programme. Also, findings at this level revealed a significant relationship between women's strong interaction with people and their involvement in a community development project (OR 4.90; $\mathrm{p}<0.05$; C.I. $2.69-$ 8.93). Women who reported that their level of literacy education made them have strong interaction with people were four times more likely to participate in community development project than their counterparts.

However, our result at this level found no significant relationship between rural women with close friends within and outside the neighbourhood and their involvement Journal of Education and Research, Vol. 9, No. 1, 2019 
Literacy Education and Social Capital| 113

in the community development project. But the result still revealed that women who had close friends within and outside the neighbourhood (OR 1.10; $p>0.41$; C.I. 0.57 2.97) were more likely to participate in community development project than their counterparts who did not have close friends within and outside their neighbourhood.

The logistic regression analysis further provided a substantial evidence that the odds of rural women's involvement in community development varies with women's participation in the decision-making process as women who participate in decision making are five times more likely to be involved in a community development project (OR 4.80; $\mathrm{p}<0.05$; C.I. $2.70-8.52$ ) than those who did not participate in the decisionmaking process in their villages. Meanwhile, the analysis at this level revealed no significant relationship between rural women's membership of development committee and involvement in community development projects, but find ings still revealed that women who were members of development committee were more likely to be involved in a community development project (OR 1.50; $p>0.05$; C.I. $0.79-2.85$ ) than their counterparts who were non-members of the development committee. There existed a significant relationship between women`s discussion of development issues with friends and their involvement in community development project as women who discuss development issues with friends are twice more likely to be involved in community development (OR 2.29; $\mathrm{p}<0.05$; C.I. 1.37 -3.82) than their counterparts who did not discuss development issues with friends.

Responses of participants from the FGD and in-depth interview reflected some of their opinions on the issues raised, findings of the quantitative data can be corroborated with the findings of the quantitative data.

For example, a literate woman in Aseigbo Village, Owena LGA commented:

... I have been able to assist my neighbours through my commitment to the community...

Another woman explained that her little education had assisted her to bond with her neighbours

... I'm the secretary and treasurer of my association; in the church also, I'm the treasurer... so, that is the way I have been helping my neighbours and my 
114 |A. C. Babalola \& T. O. Fasokun

community with my little education. [a literate woman in Ajibawo Village, Ado-Odo Ota LGA].

Using their literacy level and relationship, these women took up a leadership role in organizing the women in community development projects.

... During Adefarati regime, I was the woman leader for this local government, if am not educated, they would not choose me to lead my people... [a literate woman in Oboto Village, Ondo East LGA]

...Most of the time, those who are educated usually lead others towards development project. For instance, I do lead my people to our river to clean it up...[a literate woman in Oboto Village, Ondo East LGA]

...Apart from being a CDC member, I'm also the PRO of my association 'Ife-Lere' social club... [a literate woman in Oboto Village, Ondo East LGA

...Education is important because it helped me to be more involved in community development. [a literate woman in Aseigbo Village, Owena LGA]

... For instance, I'm the secretary and treasurer of my association, in the church also, I'm the treasurer... so, that is the way I have been helping my neighbours and my community with my little education. [a literate woman in Ajibawo Village, AdoOdo Ota LGA]

...Most of the time, those who are educated usually leading others towards

development project. For instance, I do lead my people to our river to clean it up... [a literate woman in Oboto Village, Ondo East LGA]

Keeping safe is an important part of any community. A literate woman in Oboto Village, Ondo East LGA using her literacy skills and social capital was able to give acceptable suggestions and the problem of insecurity was cubed.

... When we were being troubled by thieves, I raised a suggestion in the CDC to employ the services of security and my suggestion was accepted...

Responses from participants revealed a significant relationship between membership of community development committee and literacy. The findings above showed that the literate women were the ones mobilizing others (the non-literate as well as other literate women) and representing them at many levels. For example, most of Journal of Education and Research, Vol. 9, No. 1, 2019 
the few women who were members of the Community Development Committees were the literate ones. The literate women were able to provide leadership towards development projects. A response from a participant showed a positive relationship between participation in decision making and literacy. Raising questions on ways in which rural women's level of literacy had assisted them with their relationship with others to get involved in community development, majority of the respondents believed that their level of education had assisted their neighbours as well as their community at large as many of them usually represented their colleagues at various meetings and also served in their various capacities at one level or the other in their various community development associations. In this case, the participant, a literate woman who was a member of the community development committee in her community suggested that the services of security agents be employed to tackle the problem of insecurity. Her suggestion was accepted and that solved the problem of insecurity.

\section{Conclusion}

It can be concluded that form the findings of this study that, the level of women's participation in community development was low in terms of decision making as the number of women who were members of the decision-making committee were few although most of the few women who were members of the Community Development Committees were the literate ones.

It can also be concluded that the most significant predictors of rural women involvement in community development were: participation in adult literacy programme; literacy level; strong interaction with people; membership of community development committees; participation in the decision-making process and discussion of development issues with friends. Therefore, that the relationship between literacy and social capital is strong as the number of women who are literate and participating in community development is high; thus, literacy has a lot to do with involvement in community development. Unfortunately, most of the adult literacy centres in the rural communities visited were no longer functioning as at the time this research was carried out. This study can also conclude that social capital has a positive and significant effect on women's participation in community development. Consequently, there is the need for moribund adult education centres to be resuscitated in the rural areas as most of the centres in the rural areas visited were no longer functioning. Also, the proportion of the 


\section{$116 \mid$ A. C. Babalola \& T. O. Fasokun}

women in the community development committee/association (CDC and CDA) that should take decisions as regards any development issues should be increased.

\section{References}

Agnitsch, K., Flora, J., \& Ryan, V. (2006). Bonding and bridging social capital: The interactive effects on community action. Journal of the Community Development Society, 37(1), 36-51.https://doi.org/10.1080/15575330609490153

Babalola, A. C. (2014). Effect of literacy education and social capital on rural women's involvement in community development in Southwestern Nigeria (Unpublished doctoral dissertation). Obafemi Awolowo University, Nigeria.

Balatti, J., \& Falk, I. (2001). Socioeconomic contributions of adult learning to community: A social capital perspective. Paper presented at the ESREA (European Society for Research on the Education of Adults) Research Conference: Wider Benefits of Learning - Understanding and Monitoring the Consequences of Adult Learning, Lisbon, Portugal. https://doi.org/10.1177/074171302400448618

Bernosky de Flores, C. H. (2010). A conceptual framework for the study of social capital in new destination immigrant communities. Journal of Transcultural Nursing, 21(3), 205-211.

Bhola, H. S., \& Gomez, S. V. (2008). Signposts to literacy for sustainable development. Hamburg, Germany: UNESCO Institute for Lifelong Learning.

Buys, L., Godber, A., Summerville, J., \& Barnett, K. (2007). Building community: Collaborative individualism and the challenge for building social capital. Australasian Journal of Regional Studies, 13(3), 287-298.

Falk, I. (2001). Literacy and community: Social capital and its production of human capital (Discussion Paper D6/2001). Tasmania, Australia: Centre for Research and Learning in Regional Australia (CRLRA), University of Tasmania.

Falk, I., \& Kilpatrick, S., (2000). What is the social capital? A study of interaction in a rural community. Journal of the European Society for Rural Sociology 40(1), 87109.

Fasokun, T. O., \& Obilade, O. O. (1990). Literacy education. In L. Oyedeji \& L. Asiedu (Eds.), Principles and methods of adult education (pp. 179-199). Lagos, Nigeria: Joja Educational Research and Publishers.

Journal of Education and Research, Vol. 9, No. 1, 2019 
Graddy, E., \& Wang L. (2009).Community foundation development and social capital. Nonprofit and Voluntary Sector Quarterly, 38(3), 392-412.

https://doi.org/10.1177/0899764008318609

Grootaert, C., Narayan, D., Jones, V.N., \& Woolcock, M. (2003). Integrated

questionnaire for the measurement of social capital (SC-IQ).Washington, DC: The

World Bank Social Thematic Group.

Kilpatrick, S., \& Falk, I. (2001).Benefits for all: How learning in agriculture can build social capital in island communities. Retrieved from

https://eric.ed.gov/?id=ED461470

Moazami, M. (2006). The impacts of social capital on land consolidation projects: A case of Arak County, Iran. In S. Yokoyama \& T. Sakurai (Eds.), Potential of social capital for community development (pp. 67-104). Tokyo, Japan: Asian Productivity Organization.

Oxenham, J. (2009). Returns on investment in literacy in training and education for adult education - Quantitative findings. Retrieved from https://shorturl.at/efhsB

Smith, M. K. (2009). Social capital. Retrieved from www.infed.org/biblio/social_capital.htm

Stone, W. (2003, Spring/Summer). Bonding, bridging and linking with social capital. Stronger Families Learning Exchange Bulletin, 4, 13-16.

UNESCO. (2004). The plurality of literacy and its implications for policies and programmes (Position Paper). Paris, France: Author. Retrieved from http//unesdoc. unesco.org/images/0013/001362/136246e.pdf

UNESCO. (2009). Overcoming inequality: Why government matters (EFA global monitoring report). Paris, France: Author.

UNESCO. (2013). Literacy assessment and monitoring programme (LAMP). Paris, France: Author.

Washington State Institute for Public Policy. (2008). Adult literacy education study. Washington, DC: Becky \& Associates.

\section{To cite this article:}

Babalola, A. C., \& Fasokun, T. O. (2019). Literacy education and social capital: A study of women's involvement in community development projects in Southwestern Nigeria. Journal of Education and Research, 9(1), 91-117. https://doi.org/10.3126/jer.v9i1.28827 